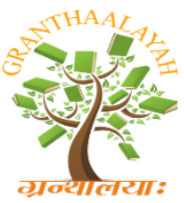

INTERNATIONAL JOURNAL OF RESEARCH GRANTHAALAYAH A knowledge Repository

Science

\title{
TUMOR METASTASIS DILEMMA: BONE SCAN AND PSA LEVEL IN RELATION TO PROSTATIC MALIGNANCY AMONG SUDANESE
}

\author{
Fahad A. Mohamed ${ }^{1}$, Yousif M. Y. Abdallah ${ }^{1,}{ }^{* 2}$, Mohamed E.M. Gar-elnabi ${ }^{1}$ \\ ${ }^{* 1}$ Radiotherapy and Nuclear Medicine Department, College of Medical Radiological Sciences, \\ Sudan University of Science and Technology, Khartoum, Sudan \\ ${ }^{2}$ Radiological Science and Medical Imaging Department, College of Applied Medical Sciences, \\ Majmaah University, Majmaah- Saudi Arabia
}

DOI: https://doi.org/10.29121/granthaalayah.v5.i5.2017.1859

\begin{abstract}
Observed the patient with prostate cancer during five years to measure the survival rate that for evaluating the effectiveness of diagnosis and treatment options.

This study conducted to study bone scan and PSA level and their relation to prostatic Malignancy among Sudanese.

This study is a retrospective cohort study, which was performed in Sudan. The sample magnitude was 306 prostate carcinoma patients with age ranged between 43-93 years. The patients' followup through 5 years studied in order to assess whether of them were alive or dead. The observed, corrected and expected five survival of the population were used. Kalban-Meier calculation methods of five years survival were used.

The study found that only 111 (36.3\%) of the 306 patients animated 5 years afterward their dates of initial management and therefore, the 5 years survival rate is $37 \%$. The study found that the survival rate were $37 \%, 42 \%$ and $44 \%(p>0.05)$ respectively.

The study found that there were many factors affected the survival rate in Sudanese population such as treatment type and diagnosis date.
\end{abstract}

Keywords: Prostate Gland; Survival Rate; Survival; Sudan.

Cite This Article: Fahad A. Mohamed, Yousif M. Y. Abdallah, and Mohamed E.M. Gar-elnabi. (2017). "TUMOR METASTASIS DILEMMA: BONE SCAN AND PSA LEVEL IN RELATION TO PROSTATIC MALIGNANCY AMONG SUDANESE." International Journal of Research - Granthaalayah, 5(5), 275-280. 10.29121/granthaalayah.v5.i5.2017.1859.

\section{Introduction}

In the Introduction section, present clearly and briefly the problem investigated, with relevant references. 
Cancer is type of disorders that branded by out of body regulator growing and antagonistic behavior. It has more than 150 types and they alienated according to their origin. It causes the harm to the body when the affected cells divide irrepressibly to produce multitudes of tissue termed tumors excepting in certain types. Tumors can rapidly proliferate and amend the functions of various body systems due to their secreted hormones. Tumors, which remain in one place and are generally considered benign. The benign tumors rest in same site and establish restricted growing rather than the malignant ones. The malignant tumors tend to brand new blood supply to nourish in a procedure named angiogenesis. Prostate cancer considers one of the furthermost tumor in world; it classify second among all cancers in both genders after breast in $2012^{1}$. It likewise the most common type among the Sudanese males ${ }^{2}$. In people with prostate cancer, the bone is usually the primary distant place of metastasis. More than two-third of secondary prostate carcinomas metastasize to the bones ${ }^{3}$. Survival ratio is an amount of existence fraction of cancer patients. It is the amount of persons who survive after a certain period after the diagnosis of the disease. Survival rates are crucial for treatment efficiency study. It depends on the entire inhabitants. Discrete prognosis is contingent on novel managements. Since the previous numerical analysis as well as the patient health condition ${ }^{4}$. The survival rate divides into many types depends on the time such as five years and ten years. It computes form the diagnosis date5. One of survival rate for assess the prognosis of disorder, generally calculated diagnosis period. The five years survival is defined as the number of patients who lived for 5 years from the tumor detection date. It used to assess the efficiency of management ${ }^{6}$.

\section{Materials and Methods}

This study was a retrospective cohort study, which was performed in amongst the cancer patients in Sudan. The sample magnitude was 306 patients with prostate cancer. The patients' age ranged between 45-95 years old. The study data was retrieved from patients' files system of Radiation and Isotopes Center of Khartoum (RICK) which included patient age, occupation, symptoms and its intervals, site of tumor and its magnitude, number of patient in year after diagnosis, number of alive at beginning of year, number of dying patient during year, Number of patients last seen alive during year. The 5-years survival rate, direct method, actuarial method and Kalban-Meier method calculation used in this study.

\section{Results and Discussions}

\section{Calculation by the Direct Method}

111 patients of total number of 306 patients were lived for 5 years. The total 5 -years survival rate of was $36.3 \%$ of all patients after estimated by the direct measurement technique. 
Table 1: Calculation of observed survival rate, and its standard error, by the actuarial (life-table) method

\begin{tabular}{|c|c|c|c|c|c|c|c|c|c|}
\hline $\begin{array}{c}\text { (1) } \\
\text { Year } \\
\text { after } \\
\text { Diagnosis } \\
\text { (i) }\end{array}$ & $\begin{array}{c}(2) \\
\text { No. alive } \\
\text { at } \\
\text { Beginning } \\
\text { of Year } \\
\left(\mathbf{l}_{i}\right)\end{array}$ & $\begin{array}{c}(3) \\
\text { No } \\
\text { Dying } \\
\text { During } \\
\text { year } \\
\left(d_{i}\right)\end{array}$ & $\begin{array}{c}(4) \\
\text { No. } \\
\text { last } \\
\text { seen } \\
\text { Alive } \\
\text { Durin } \\
\text { g } \\
\text { Year } \\
\left(\mathbf{w}_{\mathbf{j}}\right)\end{array}$ & $\begin{array}{c}(5) \\
\text { Effective } \\
\text { No. } \\
\text { Exposed } \\
\text { to } \\
\text { Risk of } \\
\text { Dying } \\
\left(\mathbf{r}_{\mathbf{i}}\right)\end{array}$ & $\begin{array}{c}(6) \\
\text { Proportion } \\
\text { Dying } \\
\text { During } \\
\text { Year } \\
\left(q_{i}\right)\end{array}$ & $\begin{array}{c}(7) \\
\text { Proporti } \\
\text { on } \\
\text { Survivin } \\
\text { g } \\
\text { year } \\
\left(\mathbf{p}_{\mathbf{i}}\right)\end{array}$ & $\begin{array}{c}(8) \\
\text { Proportion } \\
\text { Surviving } \\
\text { From list } \\
\text { Treatment } \\
\text { to end year } \\
\left(11 p_{\mathrm{i}}\right)\end{array}$ & $\begin{array}{c}(9) \\
\text { Entry } \\
(5) \\
\text { Minus } \\
\text { Entry } \\
(\mathbf{3}) \\
\\
\left(\mathbf{r}_{\mathbf{i}}-\mathbf{d}_{\mathbf{i}}\right)\end{array}$ & $\begin{array}{c}(10) \\
\text { Entry }(6) \\
\text { Divided } \\
\text { By } \\
\text { entry } \\
(9) \\
\left(\mathbf{q}_{\mathrm{i}}\right) \\
\mathbf{r}_{\mathrm{i}} \mathbf{d}_{\mathrm{i}}\end{array}$ \\
\hline o & 306 & 8 & 0 & 306.0 & 0.026 & 0.974 & 0.974 & 298 & 0.0000 \\
\hline 1 & 298 & 73 & 1 & 297.5 & 0.245 & 0.755 & 0.735 & 224.5 & 0.2450 \\
\hline 2 & 224 & 50 & 2 & 223.0 & 0.224 & 0.776 & 0.570 & 173 & 0.0013 \\
\hline 3 & 172 & 31 & 2 & 171.0 & 0.181 & 0.819 & 0.467 & 140 & 0.0013 \\
\hline 4 & 139 & 23 & 3 & 138.5 & 0.166 & 0.834 & 0.389 & 115.5 & 0.0014 \\
\hline$\geq 5$ & 113 & - & 113 & & & & & 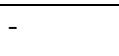 & - \\
\hline Total & & 185 & 121 & & & & & & 0.249 \\
\hline
\end{tabular}

$\left(\mathrm{r}_{\mathrm{i}}\right)_{=} \mathrm{l}_{\mathrm{i}}-\frac{w i}{2} \quad \mathrm{q}_{\mathrm{i}}=\frac{d_{i}}{r_{i}} \quad \mathrm{p}_{\mathrm{i}}=1-\mathrm{q}_{\mathrm{i}}$

\section{Calculation by the Actuarial Method (Life Table)}

The five-year survival rate measured by the life-table technique is 0.389 or $\mathbf{3 9 \%}$. The life-table method was dependable since it was founded on more data. One benefit of the life-table technique is that it offers data about vicissitudes in the risk of dying in successive intervals of observation.

Thus, column 6 (qi) shows that the amount of patients dying in each of the first 4 years after diagnosis augmented from $3 \%$ in the first year to $19 \%$ in the fourth. The increasing rates in column 8 may be used to plot a survival curve, providing a pictorial description of the survival pattern (Figure 1).

Table 2: Calculation of the corrected survival rate

\begin{tabular}{|c|c|c|c|c|c|c|c|c|}
\hline \multirow{2}{*}{$\begin{array}{c}\begin{array}{c}\text { (1) } \\
\text { Year } \\
\text { after } \\
\text { Diagnosis }\end{array} \\
\text { (i) }\end{array}$} & \multirow{2}{*}{$\begin{array}{c}(2) \\
\text { No. alive at } \\
\text { Beginning of } \\
\text { Year } \\
\left(\mathbf{l}_{\mathbf{i}}\right)\end{array}$} & \multicolumn{2}{|c|}{$\begin{array}{c}(3) \\
\text { No Dying } \\
\text { During } \\
\text { year } \\
\left(d_{i}\right)\end{array}$} & \multirow{2}{*}{$\begin{array}{c}(4) \\
\text { No. last } \\
\text { seen } \\
\text { Alive } \\
\text { During } \\
\text { Year } \\
\left(w_{i}\right) \\
\end{array}$} & \multirow{2}{*}{$\begin{array}{c}(5) \\
\text { Effectiv } \\
\text { e No. } \\
\text { Expose } \\
\text { d to } \\
\text { Risk of } \\
\text { Dying } \\
\left(r_{i}\right)\end{array}$} & \multirow{2}{*}{$\begin{array}{c}(6) \\
\text { Proportion } \\
\text { Dying } \\
\text { During } \\
\text { Year } \\
\left(q_{i}\right)\end{array}$} & \multirow{2}{*}{$\begin{array}{l}(7) \\
\text { Prop } \\
\text { ortio } \\
\mathbf{n} \\
\text { Survi } \\
\text { ving } \\
\text { year }\end{array}$} & \multirow{2}{*}{\begin{tabular}{|c}
$(8)$ \\
Proportio \\
n \\
Surviving \\
From list \\
Treatment \\
to end \\
year \\
$\left(11 p_{i}\right)$
\end{tabular}} \\
\hline & & $\begin{array}{c}\text { (a) From } \\
\text { Cancer } \\
\left(d(c)_{i}\right.\end{array}$ & $\begin{array}{c}\text { (b) } \\
\text { From } \\
\text { other } \\
\text { causes } \\
\left(d(0)_{i}\right.\end{array}$ & & & & & \\
\hline 0 & 306 & 6 & 2 & 0 & 305.0 & 0.020 & 0.980 & 0.980 \\
\hline 1 & 298 & 69 & 4 & 1 & 295.5 & 0.234 & 0.766 & 0.751 \\
\hline 2 & 224 & 46 & 4 & 2 & 221.0 & 0.208 & 0.792 & 0.595 \\
\hline 3 & 172 & 28 & 3 & 2 & 168.5 & 0.166 & 0.834 & 0.496 \\
\hline 4 & 139 & 21 & 2 & 3 & 136.5 & 0.154 & 0.846 & 0.420 \\
\hline$\geq 5$ & 113 & - & & 113 & - & - & - & \\
\hline Total & & & 185 & 121 & & & & \\
\hline
\end{tabular}


Where $\quad(r i)=l i-\frac{w i+(d(o) i}{2} \quad q i=\frac{(d(o) i}{r_{i}} \quad p i=1-q i$

The five-year corrected survival rate is $\mathbf{4 2 \%}$, compared to an observed rate of $\mathbf{3 9 \%}$. The corrected rate indicates that $\underline{\mathbf{4 2 \%}}$ of patients with Prostate Cancer escaped the risk of death from the disease within 5 years of diagnosis.

Table 3: Calculation of the relative cumulative survival rates among Prostate Cancer patients Based on data in Tables 1

\begin{tabular}{|c|c|c|c|c|c|c|c|c|}
\hline $\begin{array}{c}\text { (1) } \\
\text { Year } \\
\text { after } \\
\text { Diagnosis } \\
\text { (i) }\end{array}$ & $\begin{array}{c}(2) \\
\text { No. alive } \\
\text { at } \\
\text { Beginning } \\
\text { of Year } \\
\\
\left(\mathbf{l}_{i}\right) \\
\end{array}$ & $\begin{array}{c}\text { (3) } \\
\text { No Dying } \\
\text { During } \\
\text { year } \\
\\
\left(d_{i}\right)\end{array}$ & $\begin{array}{c}(4) \\
\text { No. last } \\
\text { seen } \\
\text { Alive } \\
\text { During } \\
\text { Year } \\
\left(w_{i}\right)\end{array}$ & $\begin{array}{c}(5) \\
\text { Effective } \\
\text { No. } \\
\text { Exposed to } \\
\text { Risk of } \\
\text { Dying } \\
\left(\mathbf{r}_{\mathrm{i}}\right)\end{array}$ & $\begin{array}{c}(6) \\
\text { Proportion } \\
\text { Dying } \\
\text { During } \\
\text { Year } \\
\left(q_{i}\right)\end{array}$ & $\begin{array}{c}(7) \\
\text { Proportion } \\
\text { Surviving } \\
\text { year } \\
\\
\left(p_{i}\right)\end{array}$ & $\begin{array}{c}(8) \\
\text { Proportion } \\
\text { Surviving } \\
\text { From list } \\
\text { Treatment } \\
\text { to end } \\
\text { year } \\
\left(11 p_{i}\right) \\
\end{array}$ & $\begin{array}{c}(9) \\
\text { Relative } \\
\text { survival } \\
\text { rate } \\
\\
\left(11 p_{\mathrm{i}} / \mathrm{E}_{\mathrm{R}}\right)\end{array}$ \\
\hline $\mathbf{0}$ & 306 & 8 & 0 & 306.0 & 0.026 & 0.974 & 0.974 & 0.974 \\
\hline 1 & 298 & 73 & 1 & 297.5 & 0.245 & 0.755 & 0.735 & 0.835 \\
\hline 2 & 224 & 50 & 2 & 223.0 & 0.224 & 0.776 & 0.570 & 0.647 \\
\hline 3 & 172 & 31 & 2 & 171.0 & 0.181 & 0.819 & 0.467 & 0.530 \\
\hline 4 & 139 & 23 & 3 & 138.5 & 0.166 & 0.834 & 0.389 & 0.442 \\
\hline$\geq 5$ & 113 & - & 113 & - & - & - & & - \\
\hline Total & & 185 & 121 & & & & & \\
\hline
\end{tabular}

$(r i)=l i-\frac{w i}{2} \quad q i=\frac{d i}{r i} \quad p i=1-q i$

$\mathrm{E}_{\mathrm{R}}=$ Expected Survival Rate $(0.88)$

Relative survival rate $=\frac{(\text { Observed survival rate })}{\text { Expected survival rate }} \times 100 \%$

Relative survival rate $=\frac{0.39}{0.88} * 100 \%=44 \%$

Table 4: Observed, corrected and relative cumulative survival rates among Prostate Cancer patients

\begin{tabular}{|l|l|l|l|}
\hline $\begin{array}{c}\text { Years } \\
\text { After diagnosis }\end{array}$ & $\begin{array}{c}\text { Observed } \\
\text { survival rates }\end{array}$ & $\begin{array}{c}\text { Corrected } \\
\text { survival rates }\end{array}$ & $\begin{array}{c}\text { relative survival } \\
\text { rates }\end{array}$ \\
\hline $\mathbf{0}$ & 0.974 & 0.980 & 0.974 \\
\hline $\mathbf{1}$ & 0.735 & 0.751 & 0.835 \\
\hline $\mathbf{2}$ & 0.570 & 0.595 & 0.647 \\
\hline $\mathbf{3}$ & 0.467 & 0.496 & 0.530 \\
\hline $\mathbf{4}$ & 0.389 & 0.420 & 0.442 \\
\hline $\mathbf{Z}$ & & & \\
\hline
\end{tabular}




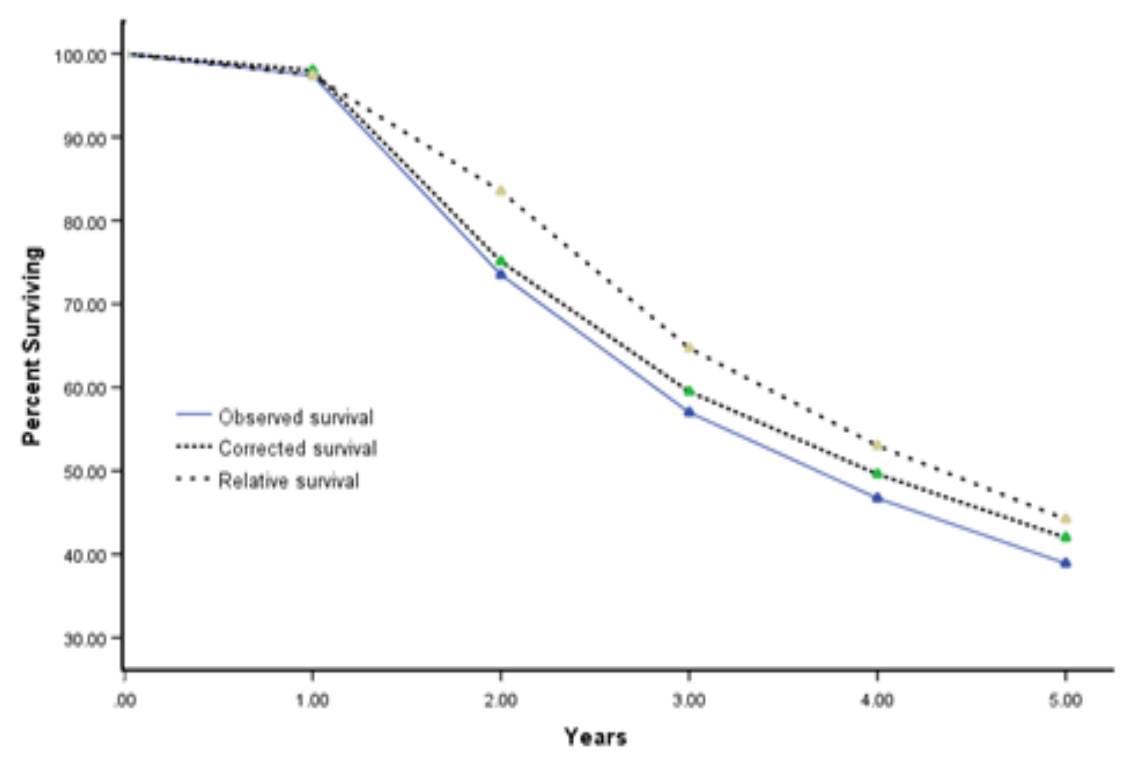

Figure 1: Observed, corrected and relative cumulative survival rates among Prostate Cancer patients Based on data in Tables 1 and 2 and 3.

\section{Conclusions \& Recommendations}

The 5-years survival rate was $91.6 \%$ for patients who diagnosed in grade 1 of the disease, $76.5 \%$ in grade 2, 24\% in grade 3 and $7.5 \%$ in grade 4 . For all study samples, no one diagnosed in grade 0 . From all patients who treated within the first month after the diagnose there are $68 \%$ survived more than 5 years, $36.5 \%$ for those who treated within the second month,29.3\% for the third month, $19 \%$ for the forth , $12.5 \%$ for the fifth month and $7 \%$ for patients who treated after more than 5 months from their diagnose. The best treatment given was the combination between surgery and radiotherapy which used for $21.2 \%$ of patients and resulted in $61.7 \%$ 5-years survival rate, followed by radiotherapy, chemotherapy, radiotherapy and chemotherapy, surgery and chemotherapy, and surgery+ radiotherapy+ chemotherapy these protocols used for $31.9,13.1,24.3,2.5$ and $1.9 \%$ of all patients respectively and resulted in $21 \%, 6 \%, 6 \%, 0 \%$ and $0 \%$ 5-years survival rates respectively. Patients of the age group of 20-30 years were $11.2 \%$ from all patients and their 5-years survival rate was 50\%, 31-40 years group was 15.6\% from all patients and survived by $48 \%, 41-50$ years group was $21.8 \%$ of all patients and survived by $34.3 \%$, age group of 51-60 was $25 \%$ from all patients and there are $30 \%$ survived from this group, 61-70 years group was $20 \%$ and survived by $21.8 \%$, the group of $71-80$ years was $5 \%$ from all patients and there were $25 \%$ survived and the age group of $81-90$ years was $1.8 \%$ from all patients and survival rate in this group was $0 \%$. The observed, corrected and relative 5-years survival rate of cancer in Sudan are $40.5 \%, 52 \%$ and $47 \%$ respectively. The study found that the survival rate of prostate were $37 \%, 42 \%$ and $44 \%(\mathrm{p}>0.05)$ respectively.

\section{References}

[1] Gowreesh, S., Sreenivasalu Reddy, N. and Yogananda Murthy, NV. Convective Heat Transfer Analysis of a Aero Gas Turbine Blade Using Ansys, International Journal of Mechanics and Solids. 4, 2009, 39-46. 
[2] Ferlay,J.,Soerjomataram,I.,M.Ervik, R.Dikshit,S.Eser and C.Mathers,2012.Cancer Incidence Mortality Worldwide. IARC Cancer Base.

[3] Khalid KE., AI.Brair, AM.Elhaj and KE.Ali, 2011.Prostate-specific antigen level and risk of bone metastasis in Sudanese patients with prostate cancer. Saudi J. Kidney Dis. Transpl., 22:10411043.

[4] Fizazi K.,M.Carducci and M.Smith,2011.Denosumab versus zoledronic acid for treatment of bone metastases in men with castration-resistant prostate cancer: A randomised, double blind study,377:813-822.

[5] "NCI Dictionary of Cancer Terms", National Cancer Institute, Retrieved 2016-04-22.

[6] Cancer survival rate: A tool to understand your prognosis - MayoClinic.com". Retrieved 2009$10-11$.

[7] Gordis and Leon, 2008.Epidemiology with Student Consult Online Access, Philadelphia,Saunders, ISBN 1-4160-4002-1, page:318.

[8] Jensen,O.M., D.M. Parkin, R. MacLennan, C.S. Muir and R.G.Skeet,1991.International Agency for Research on Cancer, Analysis of survival, Lyon, France Pages 159-176.

[9] Cutler,S.J. and F. Ederer,1958. Maximum utilization of the life table method in analyzing survival, J. Corn. Dis 8; 699-712.

*Corresponding author.

E-mail address: yousifmohamed@ sustech.edu 